\title{
宇宙用アクティブリンプロボット 関節の開発*1 Development of an Active Limp Controlled Space Robot Joint
}

\author{
西田 信一郎*2 ·吉川 恒 夫*3
}

Shin-ichiro Nishida and Tsuneo YoshiKawa

Key Words : Space Robot, Force Control, Torque Sensor, Joint Mechanism, Assembling, Manipulator

\begin{abstract}
The active limp joint was developed for the purpose of the joint for space robots from which good compliant nature is obtained to pulling in by the attaching mechanism in on-orbit assembly work. The contact work in on-orbit assembly work was analyzed, and joint active limp control was proposed as a force control system which realizes compliant action. Moreover, the small cable lap mechanism of the torque sensor of high stiffness and disturbance torque was developed. The space robot joint mechanism which these are built in was developed, and it verified that forcing for the object by application of fine joint torque sensor and joint compliance control could be performed by characteristic testing. Furthermore, it verified that good compliant action was realizable to pulling-in action by joint active limp control. Thus, the joint mechanism and control system suitable for the next-generation space robot arm which does on-orbit assembly work were developed.
\end{abstract}

1. 緒言

ロケットの直径の制約により，軌道上に打ち上げられる 構造物の大きさは高々直径 $4 \mathrm{~m}$ 程度までであり, 冡れ以上 の径の構造物は展開式の構造とするか，または軌道上で組 み立てる必要がある．しかし，展開式構造は径が大きくな るに従って複雑な構成となり，ヒンジの多用により形状精 度が悪くなるという問題がある.このため，筆者らは宇宙 ロボットを用いた軌道上組立による軌道上大型構造物構築 を検討している( 3) . 宇宙ロボットが作業する無重力環境で は, ロボットで取り扱う機器やロボット自身を常に構造物 に固定しないと浮遊してしまう.このため, 組立構造部材 の把持・分離などは部材の一端がワークサイトに固定された 状態で実施する必要がある. 兴の際にロボットアームは , 先 端および基部の両端が固定された閉リンク状態となるため， 不整定状態の回避のため, 従動動作による位置ずれ補正が 必要である . スペースシャトルのロボットアーム (SRMS) 等では, 差動遊星減速機の適用によりアーム関節の負荷側 からのバックドライバビリティ (Back-drivability) を確保 し，パツシブな従動動作によって，把持作業や把持物の固定 作業における位置・姿勢ずれを吸収している4) . しかし，差 動遊星減速機は構成が複雑であり，バックドライブ可能と はいえ，従動動作においては少なからぬ抵抗トルクが発生 するため, 結合機構やロボットのエンドェフェクタには大 きな発生力が要求される.技術試験衛星 VII 型 (ETS-VII) のロボットアームでは, アーム先端部に設けた 6 軸力覚セ

\footnotetext{
*1 C) 2004 日本航空宇宙学会

平成 15 年 11 月 25 日原稿受理

*2 宇宙航空研究開発機構

*3 京都大学大学院
}

ンサ信号のフィードバックによるアクティブな従動制御が 実施され，良好な従動特性が得られた5).このロボットアー ムは, $2 \mathrm{~m}$ 程度の短いアームであつたが, 軌道上での組立 作業に供する長い宇宙ロボットアームにおいては, 介在す る構造の柔軟性によりアーム先端部のセンサを用いた力覚 制御系の制御帯域を広く設定することに大きな困難が伴う． また，組立部材のように大きな把持物を扱う場合，6軸力 覚センサのモーメント検出レンジの不足が問題となる. ルクセンサを内蔵する関節については，これまでに各種の 試作が行われている6,7) . 但し，これらは地上向けであり， 宇宙機への搭載化を意識した構成やモジュール化が图られ ていない，本論文では，軌道上での組立作業に適した良好 な従動性能のロボットの開発を目的として，アクティブな 従動機能を有する新たな宇宙ロボット関節を開発し，光の 従動特性を実験により確認した結果について記述する。ま ず, 軌道上での組立作業の分析により，把持作業や部材の 結合作業に必要なタスクを検討し, 位置決めに加えて押し 付けと引き込みへの従動動作で構成できることを確認した . 次に従動動作を良好に実現するための制御方式としてアク ティブな従動制御である関節アクティブリンプ制御系と，こ の制御系を適用できる関節として関節の出力軸部に風性が 高く計測の安定性の高いトルクセンサを有し，従動制御の 外乱源となる関節通過ヶーブルの曲げ強さや摩擦を低減し たケーブルラップ機構を内蔵した関節機構を開発した . ま た，この関節の試験により，性能・機構特性を確認した .さ らに , 関節アクティブリンプ制御を適用した動作試験によ り，引き込みに対する追従動作が良好に行えることを確認・ 評価した。本論文では,これらの開発および試験/評価結果 について記述する。 


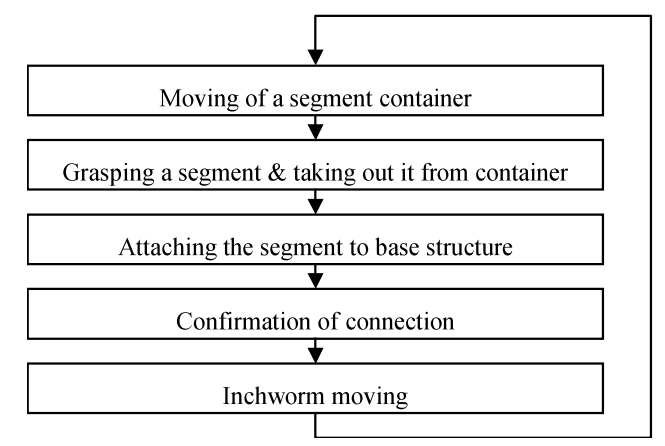

第1図＼cjkstart組立作業フロー

第 1 表 構造物組立作業の接触タスク内容

\begin{tabular}{clll}
\hline Tasks & Alignment to & Pushed to & Pulled by \\
\hline $\begin{array}{c}\text { Grasping a } \\
\text { segment }\end{array}$ & Grip & Grip & Fingers \\
$\begin{array}{c}\text { Attaching the } \\
\text { segment to }\end{array}$ & $\begin{array}{l}\text { Connecting } \\
\text { mechanism }\end{array}$ & $\begin{array}{l}\text { Connecting } \\
\text { mechanism }\end{array}$ & $\begin{array}{c}\text { Connecting } \\
\text { mechanism }\end{array}$ \\
$\begin{array}{c}\text { Inchworm } \\
\text { moving }\end{array}$ & Grip & Grip & Fingers \\
\hline
\end{tabular}

2. 宇宙ロボットによる組立作業動作

2.1 想定作業 機器の固定や結合作業においてアライ メント・嵌合のための結合力をアームの発生力に依存する と, 特に大きな要素を扱う長大なアームでは, 関節に要求 される発生トルクが大きくなり, アームの肥大化・重量増 大を招く . 乥こで, 軌道上での構造物組立・保守サービス において想定される作業について, 結合力をアームの発生 力に依存せず, 極カエンドェフェクタや結合機構の発生す る内力に依存する方針を採る。これにより，軌道上での組 立作業は尺取り虫移動，部材の取っ手 (Grip) 把持, 運搬, 組み付け (結合) などの作業と第 1 図に示した作業フロー で構成できる．また，対象物に接触する各作業タスクの内 容を分析した結果を第 1 表に示す. 各作業タスクともに対 象への「押し付け」やエンドェフェクタや結合機構による 「引き込み」に対するアームの従動動作が必要である . 従動 動作における抵抗力が小さいほど，エンドェフェクタや結 合機構の発生力に対する要求が緩和できる「引き込み」完 了後には, いずれのタスクでも構造物を介した閉リンク状 態を生じるため, 従動動作なしでは不静定によるカ/トルク が発生する。

2.2 把持- 結合作業 組立の各タスクにおいては, 各組 立部材などの要把持物に設けた取っ手の把持および把持物 のワークサイトへの結合作業が基本タスクとなる . 把持作 業の基本フローを第 2 図に示す . エンドェフェクタ先端の ガイド構造部を取っ手の開口部人「押し付け」することに より，ある程度の位置/姿勢ずれを修正し，弚の後にエンド エフェクタの指機構による「引き込み」動作にアームが従動 して嵌合する方式を採っている、嵌合後には, 構造物とアー ムで閉リンクを成すため，良好な従動が行われないと大き な荷重か残留する . 把持物の構造物への結合作業はアーム

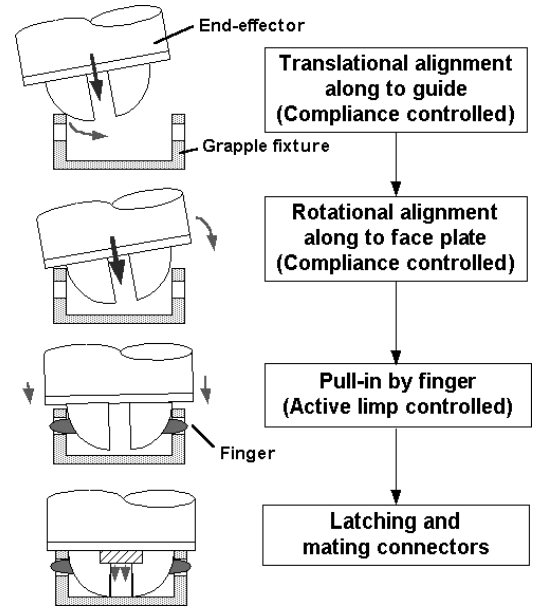

第 2 図 取っ手把持作業の基本フロー

先端がエンドェフェクタであるか把持物であるかの点で把 持作業と異なるだけであり，同樣の手順で害施できる．

\section{3. 従動性の実現方法}

ロボットアームの従動性や柔らかさを実現する代表的な 制御方式として次の方式が考えられる .

a. スティフネス制御8)

b. 力覚センサフィードバックによる力覚制御

以下では，各方式の適用性につき検討する .

3.1 スティフネス制御 パッシブリンプの代表的な方 式としては，スティフネス制御がある .この方式は, 関節 モータのサーボ岡性およびサーボ粘性などの特性の設定に より従動特性を得る方式である．モータか関節出力軸に直 結されたダイレクトドライブ関節では，摩擦が小さいため， この制御方式が有効である.しかし，ダイレクトドライブ 関節では異常時に速やかに停止できるようにブレーキ機構 が必要であるが, 宇宙用ロボット関節では真空中での摩擦 による融着などを避けるよう構成する必要があり，ダイレ クトドライブモータの出カトルクと同等の制動トルクを得 るブレーキの構成に大きな困難さがある .このため, 減速 機付きの関節への適用性を以下で検討する .

ロボットの関節に使用される減速機構においては, トル クを伝達するギアの歯の弾性変形による滑り摩擦, 力の作 用方向のずれや減速機に内蔵される軸受の摩擦などの摩擦 が介在する.この摩擦としては, 回転速度に比例する粘性 摩擦だけでなく, 静止摩擦やクーロン摩擦および伝達トル クの関数となる成分もある．減速駆動とバックドライブ状 態では，摩擦の極性が逆であるため，各々における減速機 および関節出力軸部の摩擦トルクの絶対値の 2 倍に相当す るトルクの差を生じる．また，一般にモ一タ側から回転駆 動される減速駆動状態とモータが負荷トルクに負けて関節 出力軸側から駆動されるバックドライブ状態とで咸速機の 摩擦トルクの大きさが異なり，バックドライブ時の方が大 きい，多段の平歯車の組合せにより減速比を得ている場合 には, この差が比較的小さいが, 例えばハーモニックドライ 
ブ (CSF-25-1/160) ではバックドライブ時は減速駆動時の 約 3 割増の起動卜ルクを要する ${ }^{9)}$. 光して，モータが同じ大 きさのトルクを発生しても減速駆動時とバックドライブ時 では関節出カトルクに約 $19.5 \mathrm{Nm}$ の差を生じる ${ }^{9)}$. この差 は, モータのサーボ岡性によって所望の関節剛性を得よう とするスティフネス制御においては制御誤差となる．宇宙 では, 真空潤滑部の面圧限界のために減速機の許容負荷卜 ルクが大幅に低下する ${ }^{10)}$ ため, 制御誤差か許容負荷トルク と同レベルとなる．また，モータ軸か清争止しており関節に 負荷側から加わるトルクが減速機構のバックドライブ起動 トルクを超えていない状態では, モータ軸の回転を生じな いため，スティフネス制御は従動性の効果を発揮できない

3.2 力覚センサフィードバックによるカ覚制御

3.2.1 力覚センサフィードバックの精度 力覚センサフ ィードバックでは, 減速機よりも負荷側に配したセンサによ り負荷を検出して制御するため, 減速機のバックドライバ ビリティの影響は小さい . 仮にセンサが検出レンジの $1 \% の$ 誤差を有していても，検出誤差と同等の制御誤差を見込ん でも高々許容負荷トルクの $2 \%$ 程度の誤差に過ぎない .

3.2.2 力覚センサの配置 ロボットアームの力覚制御に 使用する力覚センサの配置として，次の 2 方式が考えら れる .

a. アーム手先部に 6 軸力/トルクセンサを設ける

b. 各関節部にトルクセンサを設ける

宇宙用ロボットアームは, 重力の影響が小さいため,アー 么長を容易に長くでき，大質量物や長尺物を扱うことがで きる.このため, 低い周波数帯に構造振動モードを有する 形態となる.アーム手先部のカトルクセンサ情報で力覚制 御を行う場合, これらの構造共振か関節アクチュエータと センサの間に介在する .さらに, ペイロード有無, 質量や アーム姿勢変化により振動モード形状や固有振動数が大き く変化する.このため, 高い制御応答性を得ることが難し い.さらら , 宇宙ロボットの把持物の結合作業はロボット アーム先端から離れた部位の接触作業となるケースが多く， アーム先端部の 6 軸力覚センサには微小な並進力と広い卜 ルクの検出レンジが必要となる. 並進力の最大検出レンジ が $F$ で直径 $d$ の 6 軸カトルクセンサで計測できるトルクは 高々 $\sqrt{2} F d$ に過ぎず，さらに並進力も同時に作用する場合 には, 計測レンジのオーバフローによりトルクの計測レン ジは狭まる .このように大きさの限られたセンサで, 大き なトルク計測レンジを得ることには大きな困難が伴う．ー 方, 各関節部にトルクセンサを配置すると, センサとアク チュエータのコロケーションが成り立つため, アームや把 持物の構造柔軟性にかかわらず高い応答性を得ることがで きる．また，トルクセンサは 1 軸のトルクだけを検出すれ ばよいため，最適な構成と計測レンジ設定ができる．また， 宇宙環境而性を有する搭載計算機性能の制約と関節を通過 するケーブルの削減の観点から，各関節に関節の駆動・制 御の演算処理機能を分散させた方が有利であるが，各関節 にトルクセンサを配置する方式ではトルクセンサの回路部 を関節の駆動・制御回路と一体化でき, 力覚制御処理を分
散して処理することが可能となる点でも有利である .

4. ロボットアーム開発方針

4.1 全体構成 ロケットのフェアリングサイズとしてー 般的な $4 \mathrm{~m}$ 程度の径を想定し，これに搭載する構造要素の 径として $3.5 \mathrm{~m}$ 程度を想定する.アーム長として取り扱い 対象である構造要素の約 1.5 倍の約 $5 \mathrm{~m}$ 長を確保する.最 少関節数の基本構成のロボットアームとして, JEMRMS 親アームや ETS-VII ロボットアームの自由度配置を踏襲 した 6 自由度 (YPPPYR) アーム (第 3 図) を想定する . このロボットアームを全て同一構成の関節で構成し, 尺取 り虫型の移動を可能とする方式を検討し, 関節のエレクト ロニクス部を出力軸側の端面に配置して第 4 図のように連 結する構成を考案した .これによりロボットアームとして 組み立てた後でも関節エレクトロニクス部の着脱/調整が可 能であり，ロードパスがエレクトロニクス部を通らないと いう利点がある . 想定する主要性能を第 2 表に示す .

4.2 コントローラ 関節エレクトロニクス部には, 関節 のコントローラおよびドライバ, センサ信号処理回路, 通信 回路を配置する . 各関節エレクトロニクスおよびエンドエ フェクタのエレクトロニクスをシリアル通信系で接続し各 エレクトロニクス部の間の信号伝送を行うことにより，関 節を通過するケーブル本数を削減することができる ${ }^{11)}$. こ

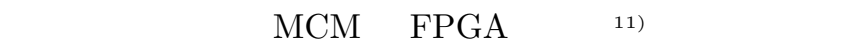
された搭載用演算処理回路で構成される. 演算処理の各工 レクトロニクスへの配分を第 3 表に示す.アームの尺取り 虫型移動に伴う倒立状態では演算処理を再配分/切り換え する .

4.3 エンドェフェクタ アーム両端のエンドエフェクタ には , 共通の構成のものを適用する . 基部側に位置した状

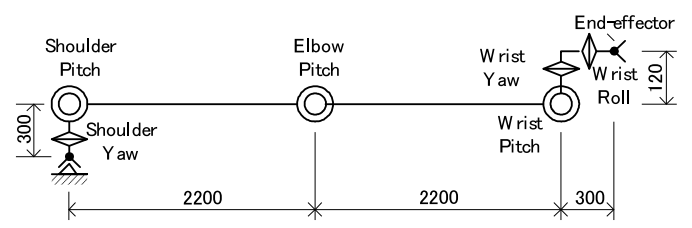

第 3 図 ロボットアームの想定自由度配置

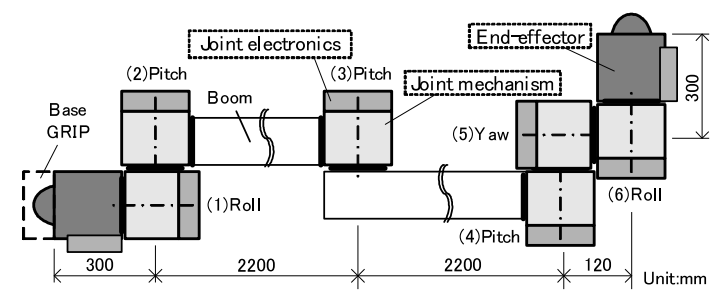

第 4 図＼cjkstart関節の連結によるロボットアーム構成

第 2 表 ロボットアームの主要性能

\begin{tabular}{lll}
\hline \multicolumn{1}{c}{ Items } & \multicolumn{1}{c}{ Characteristics } & Remarks \\
\hline Max. tip velocity & $200 \mathrm{~mm} / \mathrm{s}, 5 \mathrm{deg} / \mathrm{s}$ & Combined \\
Tip force & $10 \mathrm{~N}, 15 \mathrm{Nm}$ & Stall \\
Positioning accuracy & $5 \mathrm{~mm}, 0.1 \mathrm{deg}$ & Repeat \\
\hline
\end{tabular}


第3 表 エレクトロニクスへの演算処理配分

\begin{tabular}{ll}
\hline \multicolumn{1}{c}{ Items } & \multicolumn{1}{c}{ Allocated process } \\
\hline Tip end-effector elec. & E/E control, image processing \\
Joint electronics & Joint control, compliance \\
Base end-effector elec. & Arm kinematics, supervise \\
\hline
\end{tabular}

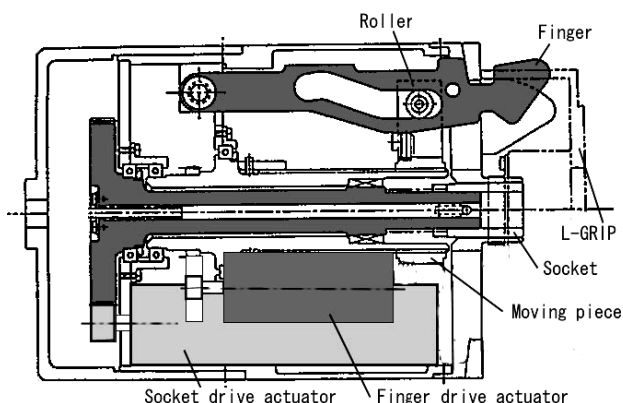

第 5 図 エンドェフェクタの内部構成

態では大きな倒れモーメントが作用するため，ロードパス が構造部材のみを通るクリップ把持型のエンドエフェクタ 機構 ${ }^{12,13)}$ (第 5 図) とカップ型の取っ手 (GRIP) を用いる ことを前提とする . また，把持作業時に十分に位置/方向が 合っていない状態からクリップ爪の動作によって引き込み が行えるようにェンドェフェクタおよび取っ手に許容ミス アライメント性能を確保する .

\section{5. トルクセンサ内蔵関節の試作}

全ての関節に適用可能な共通構成のアクティブリンプ宇 宙ロボット用関節の設計・試作の実施にあたり，以下の戦 略を採った。

a. 各軸に共通なピロー型の関節

b. 低抵抗卜ルクのケーブルラップ

c. 高剛性 , コンパクトなトルクセンサ

d. エレクトロニクスを出力軸側の端面に配置

関節の内部構成を第 6 図に示す. 以下に主要部の構成と 試作結果について述べる。

5.1 関節構成 関節は，以下の構成上の特徵を有する

・各関節に分散配置するエレクトロニクス部を関節の出力 軸側の端面に配置

・モータ側の端面と外筒の側面に接続のインタフェース面 を設ける

・ケーブルラップ機構を外筒と内筒の間に組み込む

これらにより，前記のように同一形態の関節を連結してアー ムを構成できると共に ,デリケートなトルクセンサとエレ クトロニクスを近接した配置としてノイズの影響を最小化 できる . 各関節のモータとサーボセンサの駆動・信号線は， 関節中央部に設けた貫通スリーブで関節エレクトロニクス 部と接続する形態を採った .

減速機には,ハーモニックドライブ減速機を採用した .こ れは, 構成がシンプルでありバックラッシュに相当する機 械的遊びが小さい点で有利である．この減速機構は太陽電 池パドル駆動機構 ${ }^{10)}$ や技術試験衛星 VII 型ロボットアー

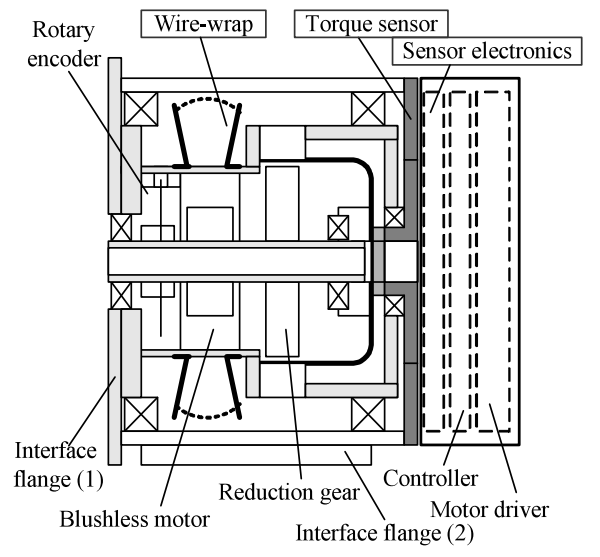

第 6 図＼cjkstart試作した関節機構の内部配置

第 4 表 既存の各種ケーブルラップ方式

\begin{tabular}{|c|c|c|}
\hline Methods & Concept & Feature \\
\hline Spiral & & $\begin{array}{l}\text { - Radial room isneeded } \\
\text {-Sticky }\end{array}$ \\
\hline Helical & & $\begin{array}{l}\text {-Tubular room isneeded } \\
\text {-Wire istwisted }\end{array}$ \\
\hline Radial tum & & $\begin{array}{l}- \text { Radial room isneeded } \\
\cdot \text { - Cable form is unstable }\end{array}$ \\
\hline Thrusttum & & $\begin{array}{l}\text {-Cable form is unstable } \\
\text {-Flat cable form is not fitted }\end{array}$ \\
\hline
\end{tabular}

$ム^{14)}$ などで軌道上での十分な実績がある. 関節真空潤滑処 理には金などが適する ${ }^{15)}$ が , 大気中での制御性能試験に用 いることを目的とした本試作機には低粘度の大気中用二硫 化モリブデングリース潤滑を施した .

\section{2 ケーブルラップ機構}

5.2.1 方式と構成 関節を通過するケーブルを関節の繰 り返し曲げ/捻りや原子状酸素による劣化から守るため, 安 定な曲げをガイドしつつケーブルをカバーするケーブルラッ フ部を設ける . 関節を通過するケーブルは関節の固定側と 出力軸の間にトルクセンサと並列に介在するものであるた め, ケーブルの曲げ反力や擦れによるトルクは直接的に関 節出カトルクの誤差要因となる

ケーブルラップ機構の方式として , 第 4 表に示す各種の 方式が知られている．しかし，いずれの方式も絡み付きに よる動作不良や抵抗卜ルク・戻りトルクの増大を生じるなど の課題があり，これを防ぐには複雑な絡み付き防止機構を 組み込む必要があった 、弚こで, 絡み付きを生じず, 安定的 な動作を保てる方式として円錐ガイド方式を新規に考案し た .この方式は,第 7 図に示す部分的にカットしたリング型 のフラットケーブルを使用し，これを円錐型のガイドに沿 わせて折り返し，折り返し部に円錐ローラのテンショナを 設けることにより，巻き付きや絡み付きを生じずに関節の 回転動作に応じたケーブル動作を行えるようにした方式で 


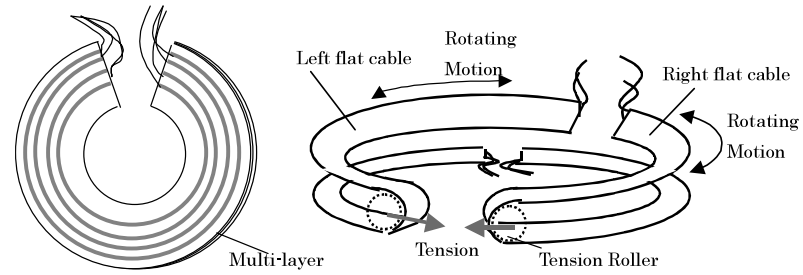

第 7 図 フラットケーブルの構成

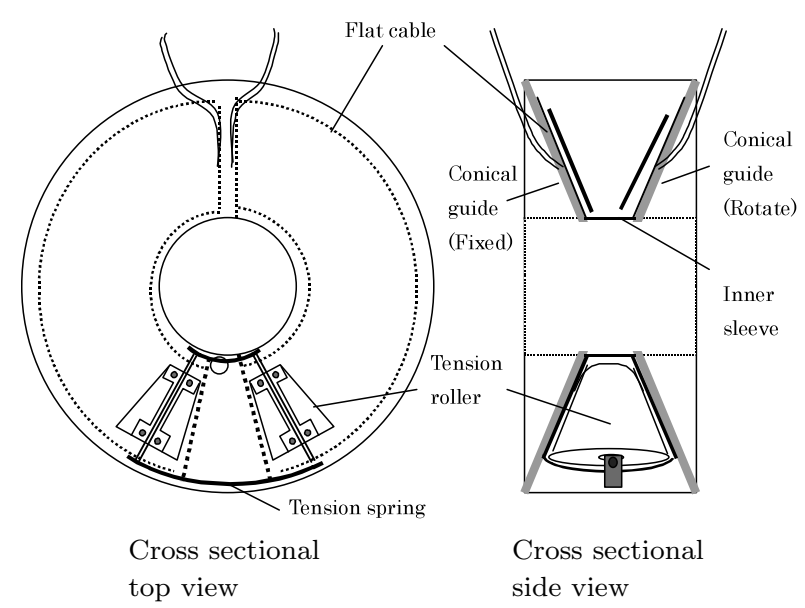

第 8 図 ケーブルラップ機構の構成

ある.構成図を第 8 図に示す．ケーブルを左右にペア構成 とすることにより，折り返しによる戻りトルクを相殺でき， 2 倍の線数を確保することができる . 各円錐型のガイドは 同軸で頂点の位置がほぼ一致した配置とする . また , テン ショナの円錐ローラの頂点も同じ位置となるように頂角と 軸方向を設定する．これによりベベルギアと同樣に円錐ガ イドの相対回転 $\theta$ に伴ってテンショナの円錐ローラが円錐 ガイド上を転がり，弚の中心軸は $\theta / 2$ 回転する . 前記のフ ラットケーブルを円錐ガイドに添わせてテンショナで折り 返せば，フラットケーブルに加わるテンションは母線に垂 直な円錐面接線方向に作用する . テンショナによりケーブ ルに適度な張力を作用させることにより，フラットケーブ ルは常に円錐ガイドに沿って貼り付いた状態に保たれ，弛 みを生じることなく回転動作に追従する．なお，関節の肥 大化を避けるため, 第 5 図に示すように関節出力軸に対に 配置されたベアリング間のスペースにケーブルラップ部を 配置した 。

5.2.2 特性試験 試作した原理モデルを用いて，本ケー ブルラップ方式での回転抵抗の特性試験を実施した . 装置構 成を第 9 図に示す.フラットケーブルには, 片面全面が銅箔 のポリエステル製 $\mathrm{FPC}$ (厚み: $0.11 \mathrm{~mm}$ ) を 2 枚重ねて使 用した . 各回転角度位置において回転動作を開始する印加卜 ルクを測定した . 試験装置の各軸受の抵抗トルクは, フラッ トケーブルを外した状態で別途測定し, フラットケーブル 付きの測定結果から差し引いた .このようにして測定した 結果を第 10 図に示す. 各角度 5 回ずつの計測の平均値と分 布範囲を示している.各角度位置において, $5.8 \times 10^{-3} \mathrm{Nm}$ 以下の抵抗卜ルクとなっており，変動は $3.8 \times 10^{-3} \mathrm{Nm}$ 以

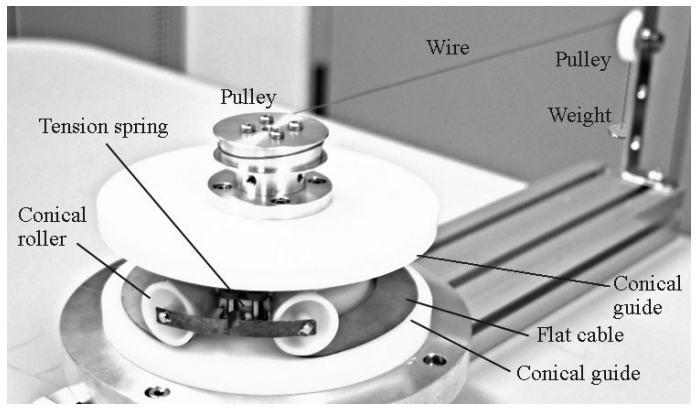

第 9 図 ケーブルガイドの構成 (機能モデル)

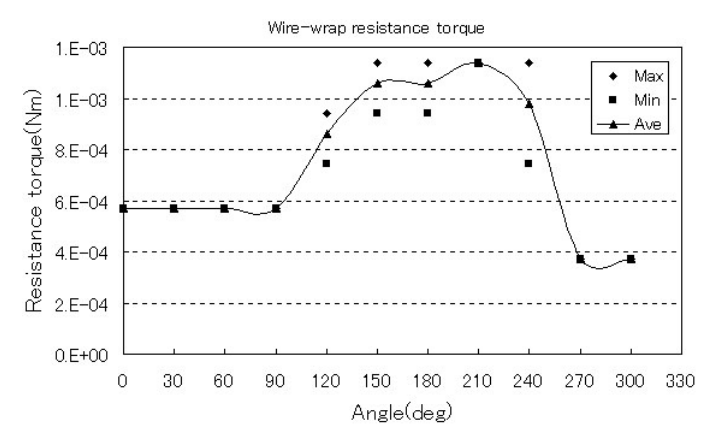

第10図 ケーブル回転抵抗測定結果

下であった .これは, 各々関節の最大出カトルク仕樣値の $0.01 \%$ 程度であり，十分に小さい值である．

5.3 トルクセンサ

5.3.1 計測部位 歪みゲージによる関節の出カトルクの 計測方法として，次の各種の方式が考えられる .

a. ハーモニックドライブに歪みゲージを貼る7)

b. ブーム構造に歪みゲージを貼る16)

c. 関節出力部に弾性部を設けて歪みゲージを貼る

ハーモニックドライブ減速機の弾性部に貼る方式もブー 么構造に貼る方式も歪みゲージの貼り付けによるトルク検 出を意図した部材構成ではないため，歪み検出に最適な部 材形状ではない．このため，高いSNR を得ることに大き な困難を伴う，一方，専用の弾性部を設ければトルク検出 に最適な構成が可能である．各々が軸受で支持された減速 機出力軸と関節出力軸スリーブ (外筒) とを接続する出力 板を弾性部材 (材質 : ステンレス鋼) とし，歪みゲージを 貼り，弚の変形からトルクを検出する方式とした .この部 材は, 内外周部が各々軸受で支持されておりトルク印加時 に捻り変形が主に生じる部材であるため, トルク検出に適 する .

5.3.2 弾性部材形状 歪みゲージを貼る弾性部材（起歪 体) 形状としては,

a. 曲げ梁部材：トルク印加時に曲げを生じる梁

b. 伸縮梁部材：トルク印加時に伸縮を生じる梁 が考えられる . 各方式の概念を第 11 图に示す . 以下では， トルクセンサの捻れによる微小変化を梁に加わる並進変位 に置き換えて検討する .

まず a について，均一な曲げ梁部材を想定し梁上の中心 


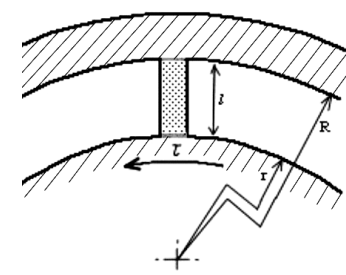

a. Bending member

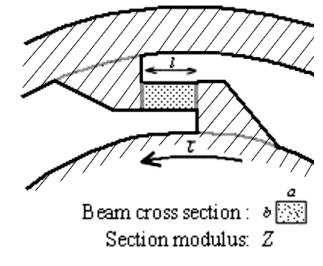

b. Compressive member
第 11 図 弾性部材の形状方式

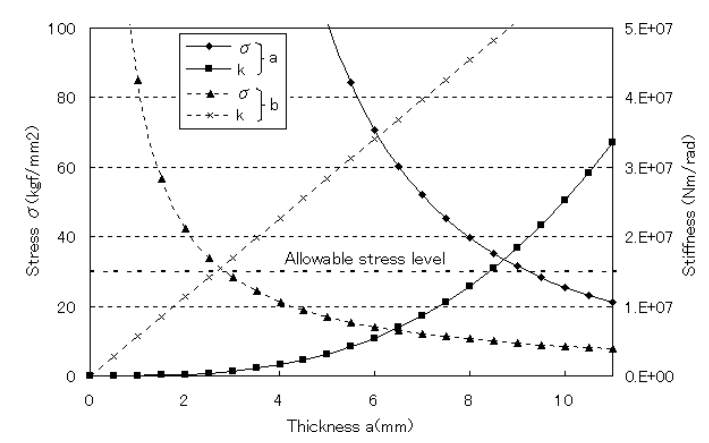

第 12 図＼cjkstart梁の厚みによる最大応力と剛性变化

軸側端からの位置を $x$ とすると, 梁 (断面係数: $Z$, 断面 積: $A=a b)$ の表面上の応力 $\sigma$ は, 径方向位置によって次 式のように大きく異なる .

$$
\sigma=\frac{\tau}{R Z}\left(\frac{R-r}{2}-x\right)
$$

ここで, $\tau:$ トルクセンサに印加されたトルク

\section{$R:$ 弾性部材外半径}

$r:$ 弾性部材内半径

即ち, 貼付位置の誤差が特性に影響し, 有限の長さを有す るゲージの貼付面に添って応力が大きく変化するため, 温 度変化の影響も受けやすい。

一方, b の伸縮梁部材では, 部材に次式に示す均一な応 カが生じ, 梁上の位置による応力の変化が少ない，

$$
\sigma=\frac{2 \tau}{A(R+r)}
$$

また，断面係数は梁部材の厚みの二乗に比例するため，曲 げ梁部材は厚みの一乗に比例する伸縮梁部材に較へて僅か な部材肉厚の誤差か計測値の誤差およひ非線形性に繋がる． 一方, 各方式で各々梁を 4 式組み込んでトルクセンサの弾 性部材を構成するとすれば, トルクセンサの捻り剛性は,

a. 曲げ梁部材 : $\quad k_{\theta B}=\frac{4 a^{3} b E R^{2}}{l^{3}}$

b. 伸縮梁部材 : $\quad k_{\theta P}=\frac{a b E(R+r)^{2}}{l}$

\section{ただし，E：弾性部材の縦弾性率}

となる. 関節の形状制約 (内半径 $r: 40 \mathrm{~mm}$, 外半径 $R$ : $80 \mathrm{~mm}$, 盤厚 $b: 6 \mathrm{~mm})$ の下で同じ長さ $(l: 20 \mathrm{~mm})$ の梁を 配置すると，両方式の弾性部材全体の岡性 $k$ と梁上の最大応 力 $\sigma_{\max }$ は梁の厚みに応じて第 12 図に示すように変化する.

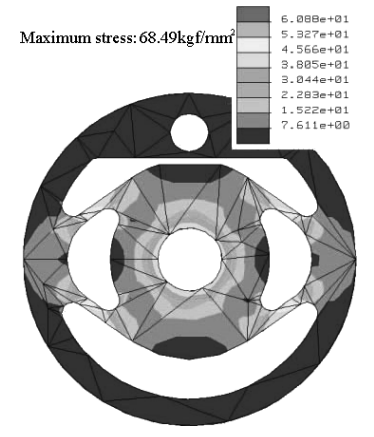

第 13 図 トルクセンサの応力分布

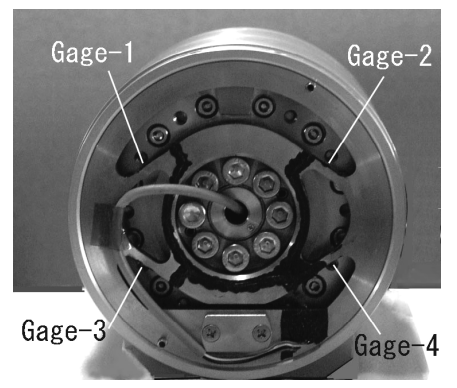

第 14 図 トルクセンサの外観とゲージの配置

関節の負荷トルクの最大値に対して梁上での最大応力か設計 基準として設定したステンレス材の許容応力 $30 \mathrm{kgf} / \mathrm{mm}^{2}$ (強度 $60 \mathrm{kgf} / \mathrm{mm}^{2}$ の $1 / 2($ 安全率 $=2)$ ) となる厚みを 選択すると，両方式での梁の厚みは各々 $9.5 \mathrm{~mm}, 3.0 \mathrm{~mm}$ となり, トルクセンサの岡性は, 各々 $2.1 \times 10^{5} \mathrm{Nm} / \mathrm{rad}$ ， $1.7 \times 10^{5} \mathrm{Nm} / \mathrm{rad}$ となる.このように同じ耐荷重性に設 計した場合，曲げ梁方式の方が僅かに高い捻り剛性が得ら れる．しかし，曲げ梁部材では，最大の歪みを生じる最大 応力が生じる部位が梁の端部であるため, 歪みゲージを貼 り付けることが困難である .このため，このケースにおい て，5 mm ずらした位置に貼ると，光の部位の歪みは端部 の約 $1 / 2$ となる.このため，伸縮梁方式の方が 2 倍高い感 度が得られる . 以上のことから, 総合的には伸縮梁方式が 有利であると判断されるため，伸縮梁部材に歪みゲージを 貼る方式を採った . 試作したトルクセンサの関節最大トル ク印加時の応力解析結果を第 13 図に示す. 伸縮梁部材上 の応力分布がかなり均一であることが解る．また，関節に 組込んだ状態の外観と歪みゲージの配置を第 14 図に示す. 回転軸を挟んで対称な配置のスポーク部材に計 4 枚の歪み ゲージを貼り，ホイートストンブリッジを構成した . 温度 補償には，スポークの裏側にもゲージを貼ることで対応で きる、なお，専用に試作したセンサ回路部 (アンプ，A/D 変換器, $\mathrm{DC} / \mathrm{DC}$ 変換器) を第 15 図に示す.この回路は, 宇宙用部品で置き換えられる部品を用いて関節に組込可能 な基板形状で構成した 。

\section{6. 接触動作のための力覚制御}

組立作業における接触動作において良好な力覚制御精度 と応答性を確保するために以下の戦略を採る。 


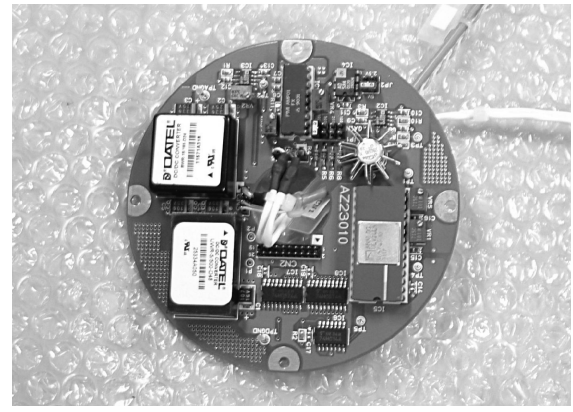

第15図 トルクセンサ回路部

a. 押し付け動作 : 関節コンプライアンス制御の適用と仮 想コンプライアンス中心角度の管理

b. 引き込み動作 : 関節アクティブリンプ制御による良好 な従動性確保

6.1 関節コンプライアンス制御 把持作業や把持物の結 合作業においては，アームまたは把持物の先端部が対象に 接触し , コンプライアンス制御によりガイド構造に押し付け て位置ずれを修正する . 関節トルクセンサの情報をフィー ドバックして関節単位のコンプライアンス制御系により， アームのコンプライアンス制御を実現することを検討する 目標とするアーム先端の仮想岡性 $\boldsymbol{k}_{\mathrm{TIP}}$ を関節単位のコン プライアンス制御で実現するためには，仮想仕事の原理よ り次式で求められる $\boldsymbol{k}_{\mathrm{JNT}}$ が関節の仮想捻り剛性の目標と なる 。

$$
\boldsymbol{k}_{\mathrm{JNT}}=\boldsymbol{J}^{\mathrm{T}} \boldsymbol{k}_{\mathrm{TIP}} \boldsymbol{J}
$$

ここで， $J$ は関節系からアーム先端系へのヤコビ行列であ る.静的な動作についてアームの慣性を無視すれば, 仮想仕 事に対する仮想変位の微分についても同樣の関係が成立す ることから，仮想粘性についても同樣に次式で求められる

$$
\boldsymbol{c}_{\mathrm{JNT}}=\boldsymbol{J}^{\mathrm{T}} \boldsymbol{c}_{\mathrm{TIP}} \boldsymbol{J}
$$

関節 (第 $i$ 軸) のコンプライアンス制御則としては, 以下 の二階積分型のものを用いる. $\boldsymbol{k}_{\mathrm{JNT}}$ のおよび $\boldsymbol{c}_{\mathrm{JNT}}$ の非対 角成分を無視することにより次式が得られる．

$$
\begin{aligned}
\theta_{\mathrm{REF} i}= & \theta_{\mathrm{COM} i} \\
& -\frac{1}{I_{i}} \iint\left(\tau_{i}-c_{\mathrm{JNT} i} \dot{\theta}_{d i}-k_{\mathrm{JNT} i} \theta_{d i}\right) \mathrm{d} t^{\prime} \mathrm{d} t
\end{aligned}
$$

ここで, $\theta_{\mathrm{REF} i}:$ 関節の角度目標

$$
I_{i}: \text { 仮想慣性モーメント }
$$

$\tau_{i}:$ 関節トルク (トルクセンサ検出値)

$c_{\mathrm{JNT} i}:$ 仮想粘性係数

$\theta_{d i}:\left(\theta_{\mathrm{REF} i}-\theta_{\mathrm{COM} i}\right)$. 即ち, $\theta_{\mathrm{COM} i}$ からの 仮想コンプライアンス角度变位

$\theta_{\mathrm{COM} i}:$ 関節への角度指令值

$k_{\mathrm{JNT}}, c_{\mathrm{JNT}}$ の対角項の第 $j$ 項は, 各々 $\sum_{i=1}^{6} k_{\mathrm{TIP} i i} j_{i j}{ }^{2}$, $\sum_{i=1}^{6} c_{\mathrm{TIP} i i} j_{i j}{ }^{2}$ であり，第 $j$ 関節軸から各方向のアーム先
端座標軸への距離の二乗に各方向の仮想剛性，仮想粘性を 掛けた值の和となるため, 各関節軸からアーム先端までの距 離に主に依存する.このため, 各関節の仮想捻り剛性 $k_{\mathrm{JNT} i}$ および仮想粘性 $c_{\mathrm{JNT} i}$ に対角項のみを用いることにより， アーム先端作用点においては主に並進方向のみの仮想コン プライアンスがラフに実現され，(最先端部の関節の軸回り 以外の) 回転の仮想剛性が高くなる . しかし , 押し付け作 業は, 取っ手や結合機構の開口部挿入において長大な宇宙 ロボットアームの並進の位置ずれを補正することが目的で あり，姿勢調整は次の関節アクティブリンプ制御による引 き込み動作により実現するため，これは問題とはならない． また, 非対角項を用いると関節間の力覚制御系の干渉を生 じ，関節ごとの独立制御による高速化の意図に反するため， 対角項のみを用いることとした .

6.2 関節アクティブリンプ制御 関節コンプライアン ス制御では, 角度指令值 $\theta_{\mathrm{COM} i}$ に対する $\theta_{\mathrm{REF} i}$ の角度变位 に応じて (7) 式右辺第 2 項より静的には $k_{\mathrm{JNT} i} \times \theta_{d i}$ に相 当するトルクを発生する．しかし，このトルクが角度変位 の増大に伴い無視できないレベルとなり従動動作の妨げと なる、例えば，直径 $10 \mathrm{~cm}$ の取っ手に対して $1000 \mathrm{Nm} / \mathrm{rad}$ の仮想コンプライアンス剛性を有するアームで $20 \mathrm{~N}$ の力 で押し付けを行っても，姿勢合わせのための結合部の倒れ 方向のモーメントとして $1 \mathrm{Nm}$ しか発生できず, 0.06 度程 度の姿勢修正量が上限となる. 即ち，これ以上の姿勢ずれ があった場合には，姿勢ずれが残ってしまう. 弚こで，コ ンプライアンス制御による仮想変位である (7) 式の右辺第 2 項に対する積分ループを追加することにより，仮想コン プライアンス中心を従動方向に移動させて仮想変位をゼロ に収束させる特性を加える .これにより，アクティブなリ ンプ動作を行うことができる（7) 式のラプラス変換に仮 想コンプライアンス積分特性を付加することにより，関節 の角度制御目標 $\Theta_{\mathrm{REF} i}$ は $s$ 領域では次式で表される。

$$
\begin{aligned}
\Theta_{\mathrm{REF} i}(s)= & \Theta_{\mathrm{COM} i} \\
& -\left(1+\frac{\omega_{I}}{s}\right) \frac{T_{i}}{I_{i} s^{2}+c_{\mathrm{JNT} i} s+k_{\mathrm{JNT} i}}
\end{aligned}
$$

ここで, $\omega_{I}$ は，リンプ補償係数である . 外力のこれより低 い周波数成分に対してアクティブリンプ制御は, 仮想コン プライアンスの反力を軽減する効果がある。

制御ブロック図を第 16 図に示す . アクティブリンプ制御 では，低周波域のゲイン補償を付加しているだけであるた め,コンプライアンス制御と変わらぬ安定性を得ることが 可能である .これは，アクティブリンプ制御) を関節レベ ルで適用した制御であり，外力により仮想コンプライアン ス中心が変位すると同時に仮想コンプライアンス中心に対 する仮想コンプライアンス変位を生じた位置を新たな角度 制御目標とした制御であると考えることができる .

\section{7. 試 験 · 評 価}

7.1 基本特性 試作した関節の基本性能や質量を測定し 


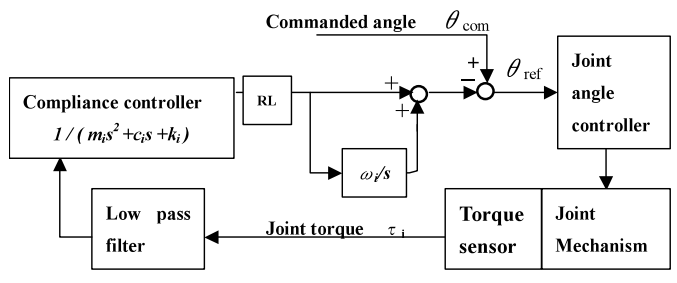

Note: RL $=$ Rate Limiter

第 16 図 関節アクティブリンプ制御

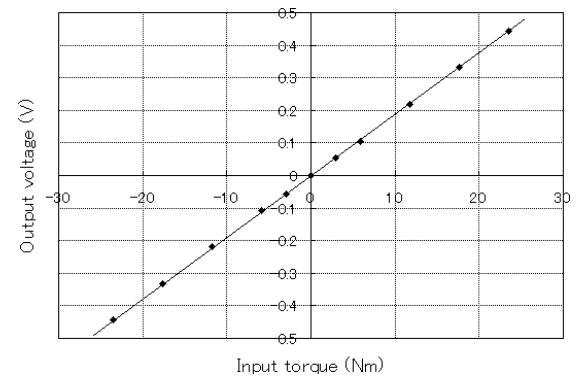

第 17 図 トルクセンサの出力特性

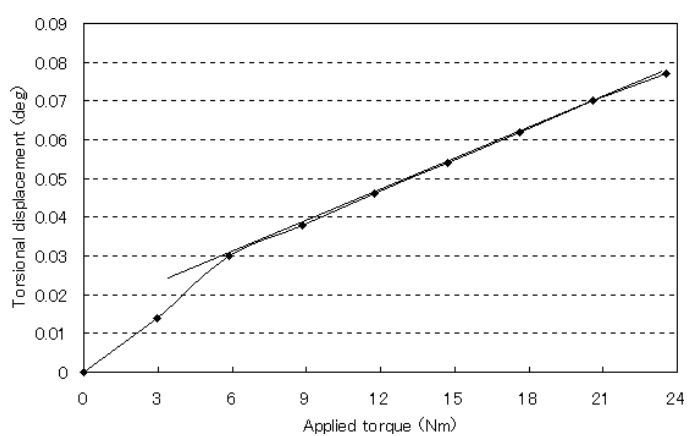

第 18 図 トルクセンサ内蔵関節の岡性特性

第 5 表 関節機構試作機の目標性能と測定結果

\begin{tabular}{lcc}
\hline \multicolumn{1}{c}{ Items } & Requirements & Testing results \\
\hline Max. rate & $15 \mathrm{deg} / \mathrm{s}$ & $18.8 \mathrm{deg} / \mathrm{s}$ \\
Peak torque & $50 \mathrm{Nm}$ & $77 \mathrm{Nm}$ \\
Positioning accuracy & $0.03 \mathrm{deg}$ & $0.025 \mathrm{deg}$ \\
Weight (without elec.) & $4.0 \mathrm{~kg}$ & $2.7 \mathrm{~kg}$ \\
\hline
\end{tabular}

た結果を第 5 表に示す．また，トルクセンサ検出値の特性 を静的に調べた結果を第 17 図に示す. 関節出力軸のベア リング摩擦やケーブルラップが並列で介在する状態でも線 形性の良い計測特性が得られている．また，関節の捻り岡 性を調べた結果を第 18 図に示す . 減速機構のロストモー ションにより $0.03 \mathrm{deg}$ 以下の変位の部分では, 剛性が低 くなっているが, 光れ以上の領域ではほぼ一定の岡性（約 $\left.2.2 \times 10^{4} \mathrm{Nm} / \mathrm{rad}\right)$ 直線に乗っている.この結果は八ーモ ニックドライブ減速機の捻り剛性を含んだ関節全体の捻り 岡性を測った結果であるがハーモニックドライブ減速機単 体の剛性値 $\left(3.1 \times 10^{4} \mathrm{Nm} / \mathrm{rad}\right.$ : カタログ性能) に対して約 $30 \%$ の低下に過ぎず，関節の他の部分の弾性を考慮すると トルクセンサの付加による関節の捻り岡性の低下は小さい．

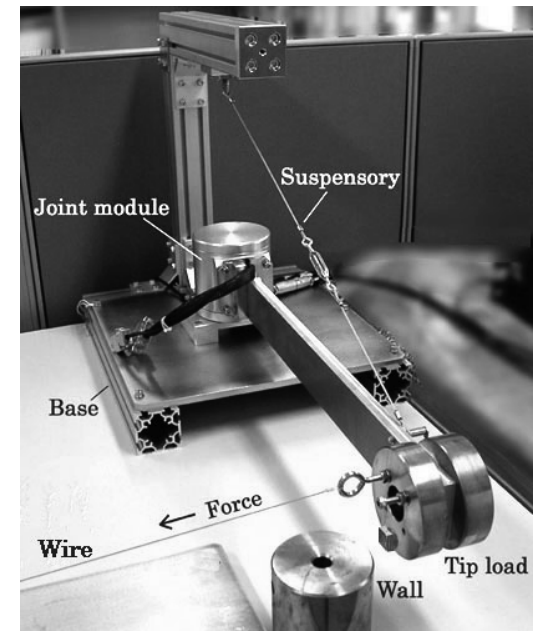

第19図引き込み追従試験装置
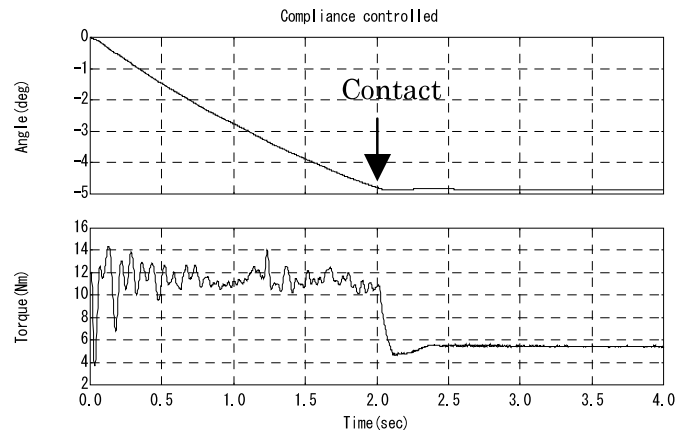

a. 関節コンプライアンス制御のケース
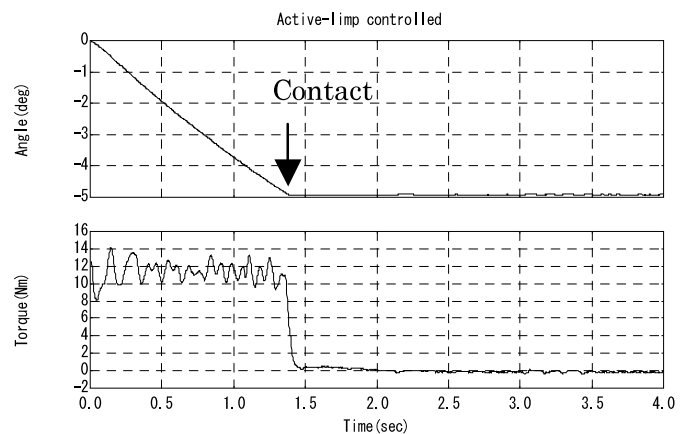

b. 関節アクティブリンプ制御のケース

第20図引き込み追従試験結果

7.2 引き込み追従試験 試作した関節を用いて一定力 による引き込み動作に対する追従性の試験を実施した .

7.2 .1 方式 関節に先端質量付きブームを接続し，一定 角度回転した位置に壁構造を設け, 鍾とプーリによる一定 外力 $(4.9 \mathrm{~N})$ に対する追従動作を行わせた .試験コンフィ ギュレーションを第 19 図に示す . 使用したコンプライア ンスパラメータは, 仮想慣性 $I i=1.24\left(\mathrm{kgm}^{2}\right)$ ，仮想粘性 $c_{\mathrm{JNT} i}=200(\mathrm{Nms})$ ，仮想岡性 $k_{\mathrm{JNT} i}=64(\mathrm{Nm} / \mathrm{rad})$. ま た，実際の負荷慣性も $1.24 \mathrm{kgm}^{2}$ である．

7.2 .2 結果, 考察 関節コンプライアンス制御およひ関 節アクティブリンプ制御での一定力での引き込みに対する 追従動作を実験した結果を第 20 図に示す．先端が $50 \mathrm{~mm}$ 
の移動後に壁に接触しているが , 関節アクティブリンプ制 御の方が速く従動し, さらに接触後の発生トルクが関節コ ンプライアンス制御 (約 $5.3 \mathrm{Nm}$ ) と較べて関節アクティブ リンプ制御では $1 / 13$ 程度の小さい接触力に (約 $0.4 \mathrm{Nm})$ 抑 制されていることが判る.これは, 関節アクティブリンプ制 御では外力印加時に外力を緩和する方向へ仮想コンプライ アンス中心が移動することによる効果であると考えられる .

\section{8. 結訔}

組立作業の嵌合フェーズにおける引き込みに対して良好 な従動性が得られる宇宙ロボット用の関節を目標として， アクティブリンプ関節を開発した . 軌道上組立作業におけ る接触作業を分析し, 従動動作を実現する力覚制御方式と して関節アクティブリンプ制御を提案した．また，高剛性 のトルクセンサと外乱トルクの小さなケーブルラップ機構 を開発し，これらを内蔵する宇宙ロボット関節機構を開発 し，特性試験により良好な関節卜ルク検出が行えることを 確認した .さらに, 関節アクティブリンプ制御により，引 き込み動作に対して良好な従動動作が実現できることを確 認した .これにより, 軌道上で組立作業を行う次世代宇宙 ロボットアームに適した関節機構および制御方式を開発す ることができた .

\section{参 考 文 献}

1) Nishida, S. and Okamura, R.: Onboard Assembling of Large Space Telescope by Space Robot, Space Factory on ISS Workshop, 1999.

2) 西田信一郎, 上野浩史, 松本秀一, 西槙健司: 軌道上組立構造要 素, 第 45 回宇宙科学技術連合講演会, 2001.

3) Nishida, S. and Yoshikawa, T.: Onboard Assembling of Large
Space Structure by Torque Controlled Space Robot, SPIE S\&S, San-Diego, 2003.

4) Taylor, H. J.: A Large Scale Manipulator for Space Shuttle Payload Handling - The Space Shuttle Remote Manipulator System, Proc. of 26th Conference on Remote Systems Technology, 1978, pp. 90-98.

5) 西田信一郎, 林 正人, 小田光茂: 技術試験衛星 VII 型ロボット への力覚制御の適用，日本機械学会論文集 C 編 , 69 (2003), pp. 187-194.

6) Pfeffer, L. E., Khatib, O. and Hake, J.: Joint Torque Sensory Feedback in the Control of PUMA Manipulator, IEEE Trans. Robotics Automation, 5 (1989), pp. 418-425.

7) Hashimoto, M., Kiyosawa, Y. and Paul, R.: A Torque Sensing Technique for Robots with Harmonic Drives, IEEE Transaction Robotics Automation, 9 (1993), pp. 108-116.

8) Salisbury, J. K.: Active Stiffness Control of Manipulator in Cartesian Coordinates, Proc. of the 19th IEEE Conference on Decision \& Control, 1980.

9) (株) ハーモニックドライブシステムズ : ハーモニックドライブ カタログ, No. 9310-2R-SF.

10）本田登志雄, 和知重雄, 橋本英一, 鈴木 孝, 松浦直人: 地球資 源衛星 1 号搭載用パドル駆動機構，第 1 回スペースエンジニア リングコンファレンス論文集 , 1992, pp. 46-53.

11）木村真一, 土屋 茂, 西田信一郎, 森谷耕太郎, 飯塚直子, 竹貝 朋樹 : 超冗長モジュール型アーム, 第 18 回日本ロボット学会学 術講演会, 1999 .

12）西田信一郎, 岡村 良 : 次世代ロボット用エンドェフェクタの試 作，第 42 回宇宙科学技術連合講演会, 1998.

13) Nishida, S., Takegai, T., Ohi, Y., Machida, K., Toda, Y. and Iwata, T.: Prototype of an End-Effecter for a Space Inspection Robot, Adv. Robotics, 15 (2001), pp. 279-285.

14）小田光茂, 稲場典康, 高野 裕, 稲垣哲也, 西田信一郎, 林 正 人, 菅野 崇: ETS-VII 型ロボット実験系の初期運用, 第 42 回 宇宙科学技術連合講演会, 1998 .

15）西田信一郎，川島教嗣 : 宇宙ロボットの搭載系技術，日本ロボッ 卜学会誌, 14 (1996), pp. 927-930.

16）小松 督, 植之原道宏, 飯倉省一, 三浦宏文, 下山 勲：トルク フィードバックを用いた宇宙用柔軟マニピュレータの振動制御， 日本ロボット学会誌, 8 (1990), pp. 39-46. 